\title{
BLENDED LEARNING: IMPROVING MOTIVATION IN LEARNING ACCOUNTING CASE OF SMK N 1 BANTUL 2012/2013
}

\author{
Oleh : \\ Alita Arifiana Anisa ${ }^{1}$ \\ Annisa Ratnasari ${ }^{2}$
}

\begin{abstract}
Abstrak
Penelitian ini merupakan Penelitian Tindakan Kelas yang bertujuan untuk meningkatkan Motivasi Belajar Akuntansi siswa kelas X SMK N 1 Bantul tahun pelajaran 2012/2013.

Penelitian ini dilakukan dalam dua siklus dengan menggunakan dua metode pengumpulan data yaitu observasi dan angket dimana data yang terkumpul kemudian dianalisis dengan analisis data kualitatif melalui tiga tahap, yaitu reduksi data, penyajian data dan penarikan kesimpulan. Analisis kualitatif tersebut kemudian dilengkapi dengan analisis statistic deskriptif untuk menghitung skor Motivasi Belajar Akuntansi.

Berdasarkan hasil penelitian disimpulkan bahwa implementasi Blended Learning dapat meningkatkan Motivasi Belajar Akuntansi Siswa Kelas X Kompetensi Keahlian Akuntansi SMK N 1 Bantul Tahun Pelajaran 2012/2013 dibuktikan dengan adanya peningkatan skor Motivasi Belajar Akuntansi kelas XAk3 dari 78,45\% pada siklus pertama dan mencapai $85,46 \%$ pada siklus kedua. Peningkatan jumlah siswa yang termotivasi dari 17 siswa pada siklus pertama dan 26 siswa pada siklus kedua memantapkan hasil penelitian bahwa Blended Learning mampu meningkatkan Motivasi Belajar Akuntansi siswa kelas XAk3 SMK N 1 Bantul secara klasikal tanpa dominasi dari beberapa siswa saja.
\end{abstract}

Kata Kunci : Blended Learning, Motivasi, Motivasi Belajar Akuntansi

\begin{abstract}
Abstact
The research is a Classroom Action Research. It aims to improve students' Accounting Learning Motivation of First Grade Accounting Competency Program at SMK N 1 Bantul Academic Year of 2012/2013.

The research which is done in two cycles uses two kinds of data collection techniques, i.e. observation and questionnaire. The data collected was analyzed by qualitative analysis using three steps, data reduction, data presentation and conclusion formulation. The analysis is completed with descriptive analysis to calculate the score of Accounting Learning Motivation.

Based on the research result, the implementation of Blended Learning is able to improve students' Accounting Learning Motivation of the first grade accounting competency program at SMK N 1 Bantul academic year of 2012/2013. It is proven by the improvements of XAk3's average score of Accounting Learning Motivation from $78,45 \%$ on the first cycle and reaches to $85,46 \%$ on the
\end{abstract}

\footnotetext{
${ }^{1}$ Alumni Prodi Pendidikan Akuntansi Fakultas Ekonomi Universitas Negeri Yogyakarta

${ }^{2}$ Staf Pengajar Jurusan P. Akuntansi Fakultas Ekononi Universitas Negeri Yogyakarta
} 
implementation of the second cycle. In addition, the increase of the number of students who are able to reach the successful criteria from 17 students on the first cycle and 26 from 33 students on the last cycle ensure the result that under Blended Learning strategy, the students' Accounting Learning Motivation is increase classically, without any domination from a few of students of the class.

Keywords: Blended Learning, Motivation, Accounting Learning Motivation

\section{A. Introduction}

Education is one of the most strategic solutions for countries that aims to improve the quality of life.According to Undang-Undang Nomor 20 tahun 2003, the objective of education is not only to transfer knowledge, but also to raise good morals, health, good skills, creativity, autonomous, democracy, and responsibility by delivering values.The goals of education can be achieved if the components of education (objectives of education, students, teachers, materials, methods, tools, and environment) make a rechiprochal relationship among them and a good performance during the implementation of teaching and learning activities (Siswoyo,2008:33). As one of the tools of education, school is a strategic meeting point for the majority components of education in a process of teaching and learning.

Teaching and learning activity is a set of interactions between teacher and students to achieve the goals (Abin, 2004:156).Sugihartono (2009:76) states that there are two factors influencing the success of learning activity, external and internal factors. External factors are the factors coming from the outside learners' selves, such as family, school, culture, and environment. Whereas, the internal factors are dividein to two, physical factors and psychological factors. The physical factors are health and physical defect. The example of psychology factors of learning is motivation. Sardiman (2009:75) defines motivation as the whole activator powers inside the learners' selves that stimulate the learning activity, keep the continuity of the learning activity, give a clear direction to learn so the objectives can be achieved.

Slavin (2009:134) says that one of the treatments that can be done by the teachers to improvestudents' motivation is using interesting and high variety of methods in transferring knowledge.Blended Learningprovides high variety of ways in providing learning materials and running learning process by combining the face-to-face instruction with computer-mediated instruction is a strategic alternative(Graham, 2004:3).Face to face may be applied in lecturing, discussion, simulation, demonstration, games, etc., While on the other side computer mediated (CM) which is an instruction helped by the internet system which is more popularlycalled by the name of electronics learning (e-learning)can be prepared in a high variety of forms, they can be take the forms of PDF, Document, Macromedia Flash, images, etc. The combination of high variety of ways in transferring knowledge in face-toface interaction and the high variety of forms of material uploaded, the using of familiar social media close to teen lifestyle, flexible access to knowledge, and cost effectiveness in CM instruction make Blended Learning is chosen as the modern solution to support the optimization of learning process through the improvement of motivation. 
Based on the observation done in the XAk3 atSMK N 1 Bantul during the accounting lesson, the researcher found that the class consists of 33 students, but not all student were motivated enough to learn. Through the observation, the researcher found that some students did not ready to enroll the class, $15,15 \%$ students on the class did not bring the homework, $21,21 \%$ students on class did not bring books to learn, they just brought the notes to record teacher's explanantion. During the lesson, researcher found that, only 2 students were participating by asking questions to the teacher, even more than $75 \%$ of the students on class were not enthusiastic in doing assignment, they were waiting for teacher explanation rather than doing the assignment. Moreover, the quality of students attendance were not good, some students came late to join the class, did not pay the attention to teachers' explanation, ask for permission to go outside the class during the lesson, discussed in peers during individual task and did not give a good respond to teacher's feeds. The ability in correlating the material learnt on class to the daily life which is important to implement the knowledge on the real life, also shows the problem, only 14 out of 33 students on class had the ability, while some others had not. In addition, $27 \%$ of students in class did not pass the minimum score of first standard competency of basic accounting subject. It means that learning objectives are not successfully reached by $27 \%$ students in XAK3.The researcher observes the facility provided by school and family also and find that SMK N 1 Bantul provides Wireless Fidelity connection and an e-learning system namely www.smkn1bantul.sch.id . Besides, all students are facilitated with cellular phone where most of their cell-phones are the sophisticated ones that allow the users to access to the internet easily by $w i-f i$ or other kinds of technology, even some other students bring notebook which may be connected to the internet.

Based on earlier explanation, Blended Learning is formulated to improve Students' Accounting Learning Motivationof First Grade Accounting Competency Program atSMK N 1 Bantul Academic Year of 2012/2013.

1. Accounting Learning Motivation

Sardiman (2009:75) defines motivation as a set of efforts to provide the specific conditions that make us want to do something.According to Shcunk, Pintrich and Meece (2009:4) there are three main terms related to the definition of motivation. First is process, motivation is a process rather than a product that may be inferred by action not verbalization. Second, motivation involves goals. Goals provide impetus for action. Last, motivation requires activity both mentally and physically. Thus, motivation is mentally and physically thing that keep us do the activity to achieve specific goals.

Guilford on Mustaqim (2008:34) says that "...learning is any change in behavior resulting from stimulation...". Furthermore, Sugihartono (2009:74) introduces learning as a process of behavior change as the result of interactions between persons and environment to fulfill their needs.He also says that the behavioral change named learning has to be done by persons in a full of consciousness, continuity, function, 
positive, activity, permanent, has a certain direction and cover all behavioral aspects such as attitude, knowledge and skill. The behavioral changes namely learning aim to achieve the three general purposes, they are gaining knowledge, implanting concept and skill and also forming attitude (Sardiman, 2009:26).

Accounting is a kind of study which learnsabout the treatment and measurement in finance. Weygant, Kieso, and Kimmel (2002:2) define accounting as an information system that contains identifying, recording and communicating the economic events of an organization to the interested users. Thus, The definition of Accounting Learning Motivation is all the activator power to make people learn and keep them learning about information system that contains identifying, recording and communicating the economic events of an organization to the interested users.

There are some kinds of motivation, i.e:

a. Innate and Learnt Motivation

Sardiman (2009:86) points out two kinds of motivation, they are Innate Motivation and Learnt Motivation. Innate Motivation means the motive which people bring since they were born, while the Learnt Motivation is the motive that emerges because of learning activities.

b. Physical and Psychological Motivation

Sardiman (2009:88) says that the experts classify the term of motivation into two, physical and psychological motivation. Physical motivation relates to reflex and desire, while the psychological motivation relates to the will formed through four moments, they are the moment when the reasons appear, choosing alternatives moment, decision making moment, and forming motivation moment.

c. Intrinsic and Extrinsic Motivation

Slavin (2009:130) classifies learning motivation according to the emerge sources of motivation into two, intrinsic and extrinsic motivation. Furthermore, Schunk, Pintrich and Meece (2010:236) explain that intrinsic motivation refers to motivation to engage in an activity for its own sake, intrinsically motivated persons work on task because they find them enjoyable and do not depend on explicit rewards or other external constraints, while the extrinsically motivated persons work task because they believe that participation result desirable outcomes such as reward, teacher's praise or avoidance of punishment.

According to Harter's theory on Motivation in Learning (Schunk, Pintrich and Meece 2010:240), the intrinsic motivation includes the following five aspects, they are:

1) Preference challenge rather than easy work.

2) Incentive to work to satisfy one's own interest and curiosity rather than working to please the teacher and obtain good grades 
3) Independent mastery attempts rather than dependence on teacher.

4) Independent judgment rather than reliance on teacher's judgment

5) Internal criteria for successful and failure rather than external criteria

Slavin (2009:132-135) formulates the ways to increase students' intrinsic motivation. First, construct students' interest by correlatting the learning material to students' daily life. Second, maintain the curiosity by using media, giving task and direct experiences, giving surprise to make them give the attention, using high variety way in providing materials, and helping the students to decide their own goals.

Slavin (2009:135) also introduces five principles that teacher has to give the attention in giving extrinsic incentive to learn. First, express the expectations clearly to ensure that students know what teacher expect them to learn, what will be evaluated and what the consequences of their achievement. Second, give clear and specific feedback about students' performance to motivate the students. Third, give direct feedback to avoid student's unsuitable understanding. Fourth, give feedbacks in often are able to maintain their positive efforts. Last, improve and access to other extrinsic motivation facilities such as notes to parents, special rights in class and other kinds of appreciation to students' performance.According to the research done by Tom Koulentes in Highland Park School the five behavior aspects show students' range of motivation are Self Readiness, Participation, Enthusiasm, Attendance, and Correlation (represent the ability of student to find the correlation between the material to the other things. (Metler, 2011:428). To assess the motivation, Schunk, Pintrich \& Meece introduces three methods, i.e Direct Motivation, Ratings by Others, and Self Report which can be done by questionnaire, interview, stimulated recalls, think-alouds, and dialogues.

2. Blended Learning

Graham (2004:3) introduces the Blended Learning system as the combination between face to face instructions and computer-mediated instructions. Furthermore, Harvi Singh and Chris Reed (2001:2) state that Blended Learning focuses on optimizing achievement of learning objectives by applying the "right" learning technologies to match the "right" personal learning style to transfer the "right" skills to the "right" person at the "right" time.Thus, Blended Learning is the learning system combines two separate models, face to face and computer mediated. The three reasons why people choose Blended Learning are first, Blended learning is able to improve pedagogy by increase the level of active learning strategies, peer-to-peer learning strategies and learners-centered strategies, where it is no secret that most current teaching and learning practice focused on transmissive 
rather than interactive strategy. Second, Blended Learning is able to increase access and flexibility, Bonk, Olson, Wisher, and Orvis 2002 on Graham (2004:8) state that access to learning is one of the key factors influencing the growth of distributed learning environment, further, they also explain that many learners want the convenience offered by distributed environment without sacrifice their social interaction and human touch when they are in a face-to-face classroom. Last, Blended learning is able to increase cost effectiveness by provides system with large opportunity reaching range, globally dispersed audience in a short period of time, and semi personal content delivery (Graham, 2004:7).

The idea of Blended Learning can be formulated through four level, they are activity level blending, course level blending, program level blending and institutional level blending (Graham, 2004:11). Besides there are three ingredients of the blending that may implements but not limited to myriad learning condition, they are:

a. Synchronous physical format using Instructor-Ied Classroom and Lecture, Hands-on Labs and workshop, and also field trips.

b. Synchronous online format (Live E-learning) using e-meetings, virtual classroom, web seminars and broadcast, coaching and instant messaging.

c. Self-paced, asynchronous formats using documents and web pages, computer-based-training modules, assessment and surveys, simulation, job aids and Electronic Performance Support System (EPSS), recorded live events, online learning communities and discussion forum.

All the levels and ingredients on Blended Learning need the internet connection to implement the computer mediated instruction. In choosing one of suitable ingredients, exploration to team, organization, infrastructure, and learners' receptiveness need to be done by considering the capability of audience to decide the delivery option will be effective in achieving goals, content selection is optimal delivery format, financial analysis both for content development and delivery cost, and infrastructure provided such as classroom capacity, mobile devices, network bandwidth and technologies (Harvi Singh and Chris Reed,2001:4). Hujair (2011:191) points out that from all the facilities provided by the internet there are five common application uses to educational needs:

1. E-mail is an electronic mail that allows two or more users to communicate asynchronously.

2. Mailing list (Mills) allows the users of e-mail to merge in an unreal time discussion to solve problems.

3. File Transfer Protocol (FTP) is a facility provided by the internet to make the users easier to look for and download the data from the server. Besides, FTP allows the users to upload home page that may be accessed all around the world.

4. News group is a facility that allows the users to communicate in a real time by applying video conferencing or chat (IRC). 
5. World Wide Web (Www) is a group of collection contains lots of kinds of documentation saved on the servers around the world developed by hypertext or hypermedia.

The other facilities on internet that teachers may utilize to integrate technology to their teaching are Facebook, Youtube, Blogs, Wikis, 3D virtual Reality Worlds, Podcast, and E-portfolio.

After discussed about the Accounting Learning Motivation and Blended Learning, the question appears is Blended Learning able to improve Students' Accounting Learning Motivation of First Grade Accounting Competency Program atSMK N 1 Bantul Academic Year of $2012 / 2013$.

\section{B. Research Method}

This research is a Classroom Action Research (CAR). CAR is an observation of teaching and learning activities in a form of action (Suharsimi,2008:3).This research is done in the first grade accounting competency program (XAk3) atSMK N 1 Bantul which is located in Jl.Parangtritis km.11 Sabdodadi Bantul in January 2013uses the Margaret Riel's model with two cycles. Each cycle contains of four steps, they are learn and plan, action, collect and analysis data and refection. The research mainly observes Accounting Learning Motivation of 33 students of XAk3. The first and second cycle will be held in two meetings of accounting subjects.

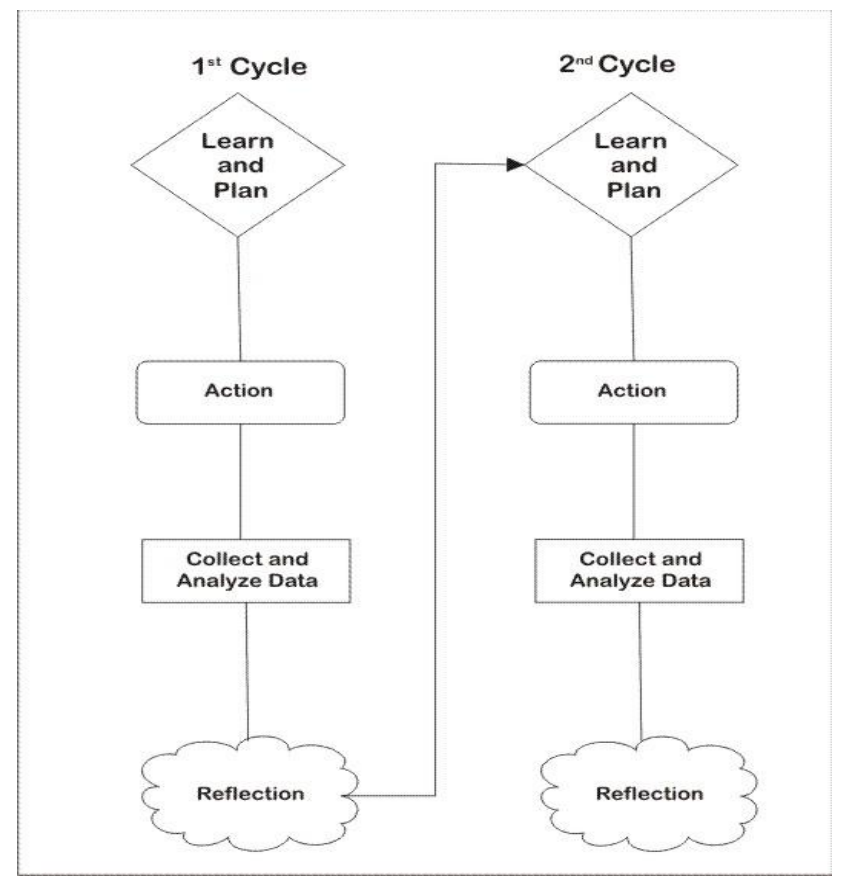

Figure 1. Process of the Classroom Action Research under Margaret Riel Model 
The research covers two variables, they are:

1. Accounting Learning Motivation

Accounting Learning Motivation is the activator power to make people learn and keep in learning about information system that contains identifying, recording and communicating the economic events of an organization to interested users. The result about Students' Accounting Learning Motivation in first cycle is going to be compared to the result from the second cycle. The motivation going to measured contains of fiveindicators, they are self-readiness, participation, enthusiasm, attendance and correlation.

2. Blended Learning

Blended Learning is defined as the combination between face to face instruction and computer mediated instruction. The learning activities will be blended at activity level blending with self paced asynchronous e-leaning that facilitated by e-learning (www.owleducenter.com), e-mail (b.learning@yahoo.com) and facebook.

The Accounting Learning Motivation data is collected by two techniques, observation and questionnaire. Observation is a kind of collection data technique that observes and records both natural and manipulated phenomenon systematically, logically, objectively and rationally (Zainal,2011:152). The observation technique aims to collect the data related to Accounting Learning Motivation that occurs during the implementation of Blended Learning. The observation also implemented to observe and record the phenomenon in the field notes which is beneficial to provide additional information and review for the next cycle. The observation uses to collect the data related to self readiness, participation, enthusiasm, and attendance. The other technique used is questionnaire. Questionaire is a written instrument to collect and record data about the information, opinion, and understanding in a causal relation (Zainal,2011:166). Questionnaire aims to collect data from students related to Accounting Learning Motivation which is going to be done after the implementation of Blended Learning in each cycle. The Questionnaire mainly aim to collect the data related to correlation. The others indicator data collected by questionnaire is self readiness, participation and enthusiasm aim to ensure the data collected by observation.

To apply the techniques mentioned above, researcher uses four instruments, they are triangulation, observation guidance, questionnaire and field notes. The data collected from the four instrument analyzed with Qualitative Analysis Technique. The researcher uses Qualitative Research Technique developed by Miles Huberman (Sugiyono,2009:246-253) that consist of three techniques, they are:

1. Data Reduction

2. Data Presentation

3. Conclusion Formulation

For the data collected by observation and questionnaire, researcher is going to uses Descriptive Analysis which means simple mathematical function to manage the data by converting data in to numerical and simple 
data (Metler, 2011:261). The data collected from observation and questionnaire analyzed by giving Accounting Learning Motivation score from 1 to 4 . According to the score, researcher calculates the percentage of students' Accounting Learning Motivation and interprets the percentage in a form of description. The analysis involves three steps, they are:

1. Determine the procedures in giving score for each indexes of Accounting Learning Motivation.

2. Calculate the score for each indicator.

3. Calculate the motivation score by the formulas:

$\%=\underline{\text { Score of Accounting Learning Motivation } \times 100 \%}$

\section{Maximum Score}

(Sugiyono,2009:137)

The research is successful when the percentage results is more than $75 \%$ students are ready, participate, enthusiasm, attend the class and able to correlate the material to daily life and previous knowledge. The student was indicated as ready, actively participate, enthusiastic, has a good quality of attendance and able to correlate the material to their daily life and previous material if they were able to reach the score of $75 \%$ for each indicator.

\section{Research Result}

The improvement from the first cycle and from the first cycle to the second cycle is shown by table 1 :

Table 1 The Improvement Analysis

\begin{tabular}{|l|l|l|l|}
\hline \multirow{2}{*}{ Indicator } & \multicolumn{2}{|c|}{ Average Score (\%) } & \multirow{2}{*}{ Improvement (\%) } \\
\cline { 2 - 3 } & \multicolumn{1}{|c|}{ First Cycle } & Second Cycle & \\
\hline $\begin{array}{l}\text { Self } \\
\text { Readiness }\end{array}$ & 81,06 & 86,74 & 5,68 \\
\hline Participation & 81,06 & 85,61 & 4,55 \\
\hline Enthusiasm & 77,27 & 87,88 & 10,61 \\
\hline Attendance & 81,82 & 90,91 & 9,09 \\
\hline Correlation & 71,02 & 76,14 & 5,12 \\
\hline $\begin{array}{c}\text { Score of } \\
\text { Accounting } \\
\text { Learning } \\
\text { Motivation }\end{array}$ & 78,45 & 85,46 & 7,01 \\
\hline
\end{tabular}

The table above shows that the score of Accounting Learning Motivation increases from $78,45 \%$ to $85,46 \%$ after the implementation of the second cycle. Besides, the improvements of students who are able to reach the successful criteria also increase from 17 students to 26 students on last cycle. 


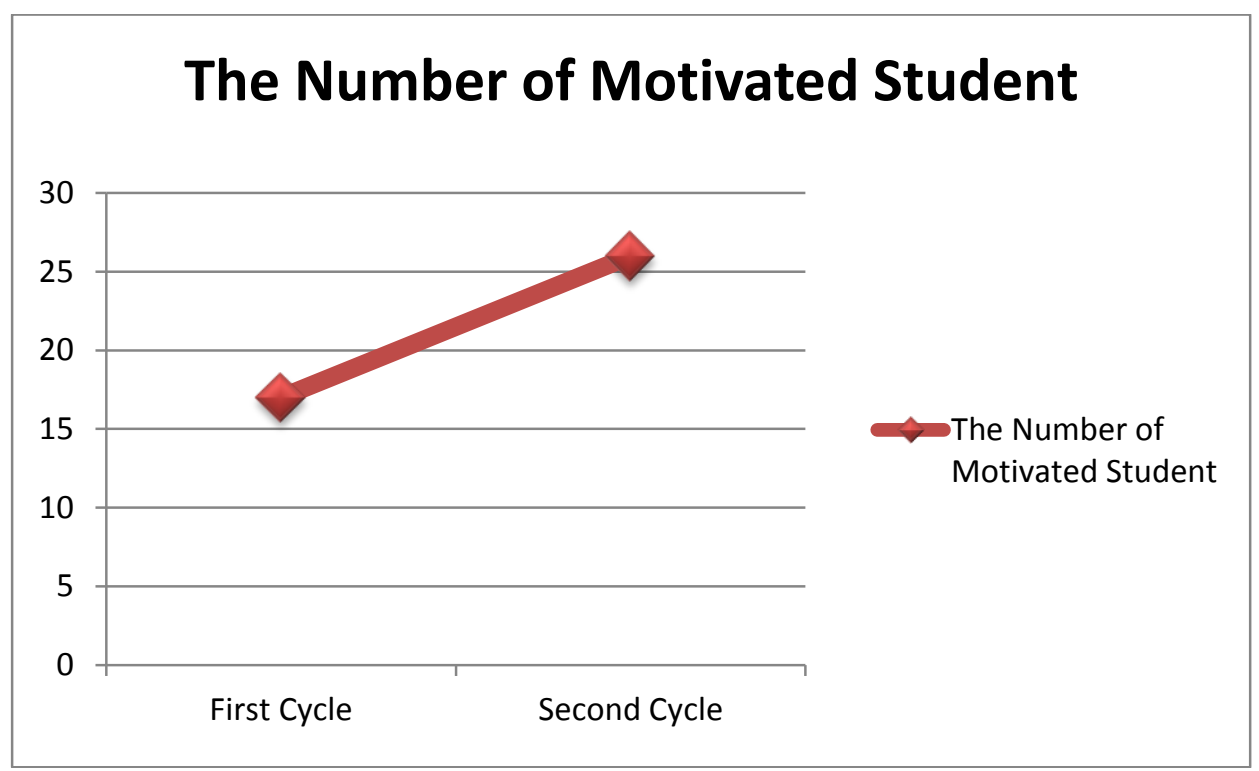

Figure 2. The Number of Motivated Students Improvement

The improvement of Accounting Learning Motivation score is because of the contribution of individual performance improvement shows on Figure 2 and the improvement of indicators score is discussed below:

1. Self Readiness

The Self Readiness indicator is collected by observation. It covers two aspect, they are readiness in preparing the material they are going to learn on the day and readiness to collect the homework given by the teacher on the previous meeting. The average score of self readiness indicator increases up to $5,68 \%$ (from $81,06 \%$ to $86,74 \%$ ). The number of students who are ready to enroll the class also increase from 27 students to 31 students out of 33 .

The improvement also occurred from the first cycle to the second cycle. The average score of motivation in the first cycle increases $5.68 \%$ in the second cycle. The number of students who are able to cover the successful criteria also increases to $96.96 \%$ students of class. The improvements explained earlier are supported by the data collected via questionnaire. Based on the questionnaire, the improvement self readiness average score from the first cycle to the second cycle reaches $1,51 \%$ from $80,56 \%$ to $82,07 \%$.

The Blended Learning Strategy stimulates the student to have better preparation to join the class by providing the supporting kinds of material uploaded to the e-learning to support students' compulsory book. Sardiman (2009:40) states that to know what to learn is the good beginning to learn. By accessing the material first, students know what they are going to learn so that they are more ready to learn. Blended Learning facilitates the student to access to the material they are going to discuss, so that while the teacher explain the material on class student has already read the material and become easier to get the knowledge teacher wants to deliver. In addition, students are able to 
give responses to teacher's feed, ask for further explanation or material that teacher forgets to explain, and do the exercise autonomously.

2. Participation

The researcher collected the data related to students' participation by the observation concerns in two aspects, they are students' participation in joining class discussion and students' participation in finishing the assignment. There are two kinds of improvement in each transition, improvement of average score and number of students who are able to reach the successful criteria. From the first cycle the average score rises $4,55 \%$ from $81,06 \%$ to $85,61 \%$ and the number of students who are able to reaches the successful criteria improves from 30 students to 33 students. The participation indicator successfully included to successful after the implementation on the first cycle, so that the second cycle concerned to keep and optimize the score of the students who are already reach the successful criteria. Besides, the second cycle is also concerns to increase the score of students who have not reach the successful criteria. The strategy for the second cycle is increasing the teacher's attention to the students who are lazy to give responses or ask questions and providing worksheet form on the elearning to increase student's time optimization to do assignment. The strategy went well, the average score of participation rises to $85,61 \%$ with all the students successfully reaches the successful criteria on the second cycle. To ensure the result of the research, researcher also analyzes the data collected by questionnaire. The questionnaire shows the improvements of participation indicator from $75 \%$ on the first cycle and reaches up to $75,51 \%$ on the second cycle.

Blended Learning strategy provides the material students going to learn, so that the students are able to read first before enrolling the class. When the teacher does the apperception, students are easily connect what the teacher explaining to the knowledge. When the teacher asks them questions during explaining the material, students are able to give responses because they have been read the material teacher talks about. Moreover, students are able to ask question about the material teacher's forget to explain, ask for deeper explanation and warn the teacher if there is any mistake in explaining the material because they had and attracted to read the interesting kinds of material. In doing the assignments, the material and exercise uploaded on the elearning also helpful for student to optimize the time allocation for assignment. They are able to finish the assignment easier when they have been attempted to finish the similar exercise on the e-learning. If the students face any difficulties in doing assignment, they are able to re-read the material on the supporting module of review the demonstration of cases on the module. The phenomenon explained by the findings of Faculty at Mercy College that the Blended learning is able to increase sense of community and collaboration because of the pedagogical strategy addressed to the high variety learning styles, 
increase interactivity, promote community and meet the special needs of online students (Dziuban, Moskal, \& Hartman, 2004:5).

3. Enthusiasm

The transition from the first cycle to second cycle shows that the average score of enthusiasm increase from $77,17 \%$ to $87,88 \%$. Besides, the number of students who is enthusiastic increases fro, 23 students to 31 students out of 33 students. As the result above, the questionnaire also show the improvement of students' enthusiasm. The questionnaire records that the enthusiasm increase from $77,27 \%$ on the first cycle and raises to $79,55 \%$ on the second cycle.

The readiness in material and another tools, such as from stimulate the students to prompt and allow the students to do their own effort to finish the assignment by read the material, looking for further explanation on book or module and compare the assignment given by the teacher to the exercise or example on the supporting material on elearning. The variances of material uploaded on e-learning attracted the students to look for the material, read the information, and do exercise themselves. Early on the first cycle, researcher provides module, PDF, and "Fling the Teacher" Games, to keep the student attracted to access the e-learning, the researcher also provides the work sheet from and various cases on the second cycle. The varieties of materials formulated and provided on e -learning become the stimulation for students to be enthusiastic to look for explanation and case demonstration in order to finish their assignment, as what Syaiful (2006:164) states that the varieties in the way to teach, interaction in learning and media causes the desire to learn.

4. Attendance

The quality of attendance cannot be manipulated by Blended Learning so that the result of the observation more depends on the environmental factors and culture as Dimyati and Moedjiono (2002:97) states that students are the part of environment so that the motivation is influenced by the environment around students, school environment, social environment and natural environment. The XAk3 at SMK N 1 Bantul has kind of culture to have lunch together on the first break. The time for lunch spent the time allocated for break so that students' quality of attendance decreases after the first break, the similar culture they do on the second break is prayer together which causes the same effect. Besides, some of students join school organization which occasionally coordinates each other on the accounting subject time. The kind of social environment at school caused the inconsistent quality of attendance. The first transition, from the pre research to the first research, the quality of attendance decrease from $96,97 \%$ to $81,82 \%$ and the number of students who own the attendance score at least $75 \%$ decrease $9,9 \%$ from $100 \%$ to $90,90 \%$. The analysis of second transition shows that average score rises from $81,82 \%$ to $90,91 \%$ with all students have the good quality of 
attendance shows by their average score of attendance which is at least $75 \%$.

\section{Correlation}

Correlation can be improved by providing cases, exercises or examples which are close to students' daily life, but it is hard to provide the cases, exercises, and examples which are able to covers all kinds of students' life background. Example A may be suitable to students A but not for student B, example B is suitable to student B but not for student A. That is why the correlation indicator is hard to design for optimal score. The score of correlation indicator is increase from $71,02 \%$ on the first cycle to $76,14 \%$ after the implementation of the second cycle.

\section{Conclusion}

\section{Conclusion}

Based on the research result and discussion, the implementation of Blended Learning is able to improve students' Accounting Learning Motivation in SMK N 1 Bantul. The judgment is proven by the increase of Accounting Learning Motivation score that is collected by observation for four indicators (self readiness, participation, enthusiasm, and attendance) and questionnaire for one indicator (correlation) and for ensuring the other three indicators (self readiness, participation, and enthusiasm) from $71,47 \%$ on the pre research to $78,45 \%$ on the first cycle and reaches to $85,45 \%$ on the implementation of the second cycle. In addition, the increase of the number of students who are able to reach the successful criteria from 17 students on the first cycle and 26 out of 33 students on the last cycle ensure the result that under the Blended Learning strategy, the students' Accounting Learning Motivation is increase classically, without any domination from a few of students on class.

2. Suggestions

a. For the Teacher

1) The Teacher needs to formulate the learning process which is able to give opportunities to the students to apply the knowledge the learnt to the daily life.

2) The teacher needs to learn how to optimize the technology to increase students' accessibility to the material.

3) The teacher needs to learn to form various kinds of material to avoid student bored.

4) The teacher has to let the students to gain other sources of knowledge especially from internet to increase students accessibility, self readiness, and decrease their dependency to teacher.

b. For the Students

1) The students need to increase their access to others sources of knowledge, especially to the more applicable cases. 
2) The students need to apply the knowledge they learnt on class on their daily life.

3) The students are able to gain more knowledge from others source and confirm to the teacher on class.

4) The students are able to open their mind to other information outside the teacher's explanation to enrich their knowledge.

5) The students need to improve their confidence to ask question or give responds to the teacher better than only accept the knowledge passively.

c. For the Researcher

1) For the better research result, the researcher needs to be more consistent in using kinds of instrument that is suitable to each indicator.

2) The researcher needs more skill in operating the e-learning to avoid errors.

3) The researcher needs to be more careful in observing students for more detail individual analysis.

\section{E. References}

Schunk, D.H., Pintrich, P.H., \&Meece, J.L. (2010). Motivation in Learning. 3 ".ed. New Jersey : Pearson Education Inc.

Dimyati \& Moedjiono. (2002). Belajar dan Pembelajaran. Jakarta : PT.Rineka Cipta.

Dzibuan, C.D.,Hartman, J.L.,\& Moskal,P.D. (2004). "Higher Education, Blended Learning and the Generations: Knowledge is a Power - No More". Retrieved February 21, 2013, from: http://www.sc.edu/cte/dziuban/doc/blendedlearning.pdf

Siswoyo, Dwi, et al. (2008). Ilmu Pendidikan. Yogyakarta: UNY Press.

Graham, Charles R. (2004). Blended Learning Systems: Definition, Current Trends, and Future Directions. San Francisco,CA: Plefier Publishing.

Singh, H. \&Reed, C. (2001). "A White Paper: Achieving Success with Blended Learning". Retrieved June, 18, 2006, from: http://facilitateadultlearning.pbworks.com/f/blendedlearning.pdf

H.J Klein, R.A Noe, C.Wang. (2006). Personnel Psychology. Wiley Online Library.

J.J Weygant, D.E Kieso, P.D Kimmel. (2002). Accounting Principles. 6”.ed. John Wiley\& Sons, Inc.

Makmun, Abin. (2004). Psikologi Kependidikan. Bandung : PT. Remaja Rosdakarya

Metler, Craig A. (2011). Action Research Mengembangkan Sekolah dan Memberdayakan Guru. Yogyakarta : Pustaka Pelajar

Mulyasa. (2009). Menjadi Guru Profesional: Mencipatakan Pembelajaran Kreatif dan Menyenangkan. Jakarta: PT. Grasindo.

Parkay, Forest W. (2010). Becoming a Teacher. 8".ed. New Jersey : Pearson Education Inc.

Purwanto, Ngalim. (2007). Psikologi Pendidikan. Bandung : PT. Remaja Rosdakarya. 
Jurnal Pendidikan Akuntansi Indonesia, Vol. XI, No. 1, Tahun 2013

Alita Arifiana Anisa \& Annisa Ratnasari

Halaman $146-160$

Sanaky, Hujair A.H. (2011). Media Pembelajaran Buku pegangan Wajib Guru dn Dosen. Yogyakarta: Kaukaba Dipantara.

Sanjaya, Wina. 2011. Penelitian Tindakan Kelas. Jakarta :Kencana.

Sardiman. (2009). Interaksi dan Motivasi Belajar Mengajar. Jakarta: PT.Raja Grafindo Persada.

Slavin, Robert E. (2009). Psikologi Pendidikan Teori dan Praktek. 8".ed. Jakarta : Indeks.

Soemarsono S.R. (2004). Akuntansi Suatu Pengantar Revisi. Jakarta: Salemba Empat.

Sugihartono, et al. (2007).Psikologi Pendidikan. Yogyakarta: UNY Press.

Sugiyono. (2009). Metode Penelitian Pendidikan. Bandung: CV Alfabeta.

Syaiful B.J. \& Aswan Z. (2006). Strategi Belajar Mengajar. Jakarta: Rineka Cipta.

Suharsimi Arikunto, et al. (2008). Penelitian Tindakan Kelas. Jakarta: Bumi Aksara.

Zainal Arifin. (2010). Evaluasi Pembelajaran. Bandung: PT.Remaja Rosdakarya. 